\title{
Lipoprotein(a)—antisense therapy
}

\author{
Anja Vogt ${ }^{1}$ \\ Published online: 11 March 2019 \\ (c) The Author(s) 2019
}

\begin{abstract}
Elevated levels of lipoprotein(a) (Lp(a)) contribute to the risk of early and severe cardiovascular disease (CVD) and Lp(a) is acknowledged as a risk factor to be included in risk assessment. The established lipid-modifying medical therapies do not lower $\mathrm{Lp}(\mathrm{a})$ except niacin but no data of endpoint trials are available. Of the new lipid-modifying drugs a few have some impact on $\operatorname{Lp}(\mathrm{a})$. Whether the $\mathrm{Lp}(\mathrm{a})$ lowering effect contributes to the reduction of CVD events would have to be shown in $\mathrm{Lp}$ (a) dedicated trials. None of the available agents is indicated to lower $\mathrm{Lp}(\mathrm{a})$. Lipoprotein apheresis lowers levels of Lp(a) significantly by $>60 \%$ per treatment. Trial data and data of the German Lipoprotein Apheresis Registry show that regular apheresis reduces cardiovascular events. The Apo(a) antisense oligonucleotide is the only approach to specifically lower Lp(a). The IONIS-APO(a) $)_{R x}$ phase 1 and 2 trials showed very substantial decreases of Lp(a) and good tolerability. The hepatospecific variant IONIS-APO(a)- $\mathrm{L}_{R x}$ is 30 times more potent. The results of the IONIS-APO(a)- $\mathrm{L}_{R x}$ phase 2 trial were presented recently. The highest dosages reduced Lp(a) by 72 and $80 \%$; in about 81 and $98 \%$ Lp(a) levels $<50 \mathrm{mg} / \mathrm{dl}$ were achieved. Tolerability and safety were confirmed, whereby injection site reactions were the most common side effects. This raises hope that the planned phase 3 trial will reproduce these findings and show a reduction of cardiovascular events.
\end{abstract}

Keywords LDL-Cholesterol $\cdot$ Lipid lowering therapy $\cdot$ Antisense oligonucleotides $\cdot$ Atherosclerosis $\cdot$ Cardiovascular disease

\section{Introduction}

In 1963 Berg described the lipoprotein(a) (Lp(a)) system in man, was the first to note that the individual level of $\mathrm{Lp}(\mathrm{a})$ is inherited and that high levels are associated with early onset of atherosclerosis [1]. In the following decades epidemiological data supported the initial findings, genetic trials confirmed that $\mathrm{Lp}(\mathrm{a})$ is a causal factor for developing atherosclerosis, and the negative impact of high levels of $\mathrm{Lp}$ (a) not only on coronary heart disease but also on development of aortic stenosis, peripheral arterial disease, and ischaemic stroke was shown [2-12]. On the other hand much is still almost unknown, e.g. the physiological role of $\mathrm{Lp}(\mathrm{a})$, the catabolism, and the clinical relevance in thrombotic and embolic events. High levels of Lp(a) are acknowledged as being associated with an increased risk of cardiovascular disease (CVD) by the 2016 European Atheroscle-

\footnotetext{
This article is part of the special issue "Lp(a) - Update 2018"

Anja Vogt

Anja.Vogt@med.uni-muenchen.de

1 Medizinische Klinik und Poliklinik IV, Klinikum der Universität München, Ziemssenstraße 1, 80336 Munich, Germany
}

rosis Society/European Society of Cardiology (EAS/ESC) Guidelines [13] and are considered to be a risk-enhancing factor by the 2018 American Heart Association/American College of Cardiology (AHA/ACC) Guideline [14]. The consensus paper of the European Atherosclerosis Society gives a comprehensive overview of $L p(a)$ as a cardiovascular risk factor [15]. The authors suggest measuring $L p(a)$ in individuals at intermediate or high risk of CVD, in case of premature CVD, familial hypercholesterolaemia, family history of premature CVD or high $\mathrm{Lp}(\mathrm{a})$, progressive CVD despite statin therapy, $\geq 3 \%$ 10-year risk of fatal CVD (European SCORE), or $\geq 10 \%$ 10-year risk of fatal or non-fatal coronary heart disease (US guidelines). Lowering LDL-c remains the first priority. Secondary a $\mathrm{Lp}$ (a) level $<50 \mathrm{mg} / \mathrm{dl}$ $(\sim<80$ th percentile) is suggested as desirable. The somewhat arbitrary cut off level of $30 \mathrm{mg} / \mathrm{dl}$ is often used based on data showing the continuous increase of risk with increasing levels of $\mathrm{Lp}(\mathrm{a})$ and without an obvious threshold value [10]. Since no endpoint data are available no target level can be specified. 


\section{Treatment options}

For statins, the backbone treatment for preventing and reducing cardiovascular events by lowering LDL-c, small decreases or increases of $L p(a)$ have been shown [16]. But mostly $\operatorname{Lp}(\mathrm{a})$ is not affected by statins $[15,17,18]$. The same is seen for ezetimibe [19].

Nicotinic acid (niacin) has a broad range of lipid-modifying effects, lowering LDL-c and triglycerides and increasing high density lipoprotein-cholesterol (HDL-c). In addition it was shown to lower $\operatorname{Lp}(\mathrm{a})$ for the first time in 1989 [20]. High doses of nicotinic acid (2000-4000 mg) are needed to reduce $L p(a)$ significantly [21]. However, this effect has not yet been shown in patients with high baseline levels of $L p(a)$ with regard to the inclusion criterion. A meta-analysis has summarised the beneficial effects of nicotinic acid on cardiovascular events [22], but it was not evaluated if the benefit is attributable to reduced levels of Lp(a). Additionally the positive effects are mainly from the pre-statin era. The EAS consensus paper states that niacin should be used to reduce high levels of $L p(a)$ because of the evidence and despite the fact that it cannot be excluded that the benefits are not attributed to lowering $\mathrm{Lp}$ (a) but to the favorable effects on other lipoproteins [15]. In 2013 the combination of extended release niacin and laropiprant, a flush inhibitor, was withdrawn from the European market after the Heart Protection Study 2-Treatment of HDL to Reduce the Incidence of Vascular Events (HPS2-THRIVE) was stopped early because of a significant increase in bleeding events, including intracranial haemorrhage [23]. Although the reasons have not been elucidated the use of nicotinic acid continues to be debated.

Lipoprotein apheresis (LA) as an extracorporeal method lowers LDL-c and $\mathrm{Lp}(\mathrm{a})$ acutely and significantly by $60-70 \%$ but has to be applied regularly (mostly weekly). Few countries consider high levels of $\mathrm{Lp}$ (a) to be an indication for lipoprotein apheresis in very high-risk patients if all other cardiovascular risk factors, mainly LDL-c, are treated optimally [24-27].

Beneficial effects of LA on the course of CVD are shown by retrospective evaluations, prospective (but not blinded, randomized controlled) trials, and analyses of the German Lipoprotein Apheresis Registry [28-35]. LA is generally well tolerated and safe $[27,36]$ but time consuming, expensive, only offered in specialised centres, and often not covered by health insurance.

\section{New drug developments}

Several new lipid-modifying drugs to reduce LDL-c are currently under investigation. They lower LDL-c and Lp(a) to varying degrees though lowering of $L p(a)$ has never been the target or a primary endpoint. Since all agents primarily lower LDL-c it would be difficult to show if the Lp(a) lowering effect is clinically relevant, as with niacin. Of these, only PCSK9 inhibitors are widely available. Both evolocumab and alirocumab lower LDL-c about 50 to $60 \%$ and in some trials the lowering of $\mathrm{Lp}(\mathrm{a})$ was assessed, too. The mechanism by which $L p(a)$ is reduced is matter of debate. With evolocumab reductions of $25.5 \%$ [37] and with alirocumab reductions of $30.2 \%$ [38] were reported. A pooled analysis [39] of three phase 2 trials using alirocumab for 8 or 12 weeks analysed the $L p(a)$ lowering effect. Levels ranged from 2 to $181 \mathrm{mg} / \mathrm{dl}$ and the two groups consisted of participants with baseline levels of $\leq 50 \mathrm{mg} / \mathrm{dl}$ and $\geq 50 \mathrm{mg} / \mathrm{dl}$. The median absolute reduction was 3.5 and $27 \mathrm{mg} / \mathrm{dl}$, respectively, the median percent reduction 36 and $27 \%$, respectively. Interestingly in patients with LDL-receptor negative homozygous $\mathrm{FH}$ evolocumab reduced $\mathrm{Lp}$ (a) by $20 \%$ while LDL-c did not decrease [40]. The upregulation of other receptors, e.g. the very low density (VLDL) receptor that mediates the uptake of $\mathrm{Lp}(\mathrm{a})$ into macrophages, might be an explanation for this finding. There are further contradictory results by what mechanism $\mathrm{Lp}(\mathrm{a})$ is reduced. Some data show an increased catabolic fraction rate, others a reduced synthesis [41]. In the FOURIER trial Lp(a) was reduced significantly by evolocumab and participants with higher absolute reductions of $L p(a)$ tended towards a greater benefit [42].

\section{Antisense oligonucleotides}

Antisense oligonucleotide (ASO) drugs are a relatively new way to very specifically target genes on the mRNA level and are used in different medical fields. Mipomersen, the first ASO used in hypercholesterolaemia, interferes with the encoding mRNA for ApoB100. The production of ApoB100 is reduced via inhibition of translation to the protein. Consequently less very low density lipoprotein (VLDL) is assembled in the liver resulting in lower levels of circulating LDL-c. As a side effect, less triglycerides are excreted from the liver and accumulate often leading to fatty liver disease and elevated transaminases $[43,44]$. By what mechanism levels of $\mathrm{Lp}(\mathrm{a})$ are lowered is not entirely clear. In four phase 3 trials mipomersen given subcutaneously versus placebo levels of $\mathrm{Lp}(\mathrm{a})$ were significantly reduced by 21-39\% [45]. Thus mipomersen might reduce the necessity for lipoprotein apheresis in high-risk patients [46, 47]. The most common side effects were severe injection site reactions and liver steatosis is also of concern. Because of the side effects mipomersen was not widely approved and is available in the USA only. 


\section{Apo(a) antisense oligonucleotide}

IONIS-APO $(\mathrm{a})_{\mathrm{Rx}}$, an antisense oligonucleotide molecule, is the first measure developed to specifically address the mRNA of Apo(a). Trials in transgenic mice [48] and phase 1 results showed relevant decreases of $\operatorname{Lp}(\mathrm{a})$. In a phase 1 trial in healthy volunteers ( $\mathrm{Lp}$ (a) levels $\geq 25 \mathrm{nmol} / \mathrm{l}$ ) IONIS-APO(a) $)_{R x}$ significantly lowered $L p(a)$ in a dose-dependent manner. The highest dose of $300 \mathrm{mg}$ reduced $\mathrm{Lp}$ (a) by $77.8 \%$. In one individual the maximal reduction was $88.8 \%$ after 36 days. Impressively $\mathrm{Lp}(\mathrm{a})$ did not increase immediately but was still low 84 days after the last application [49]. The use was safe and the most common side effects were injection site reactions. As a ligand-conjugated variant of IONIS-APO $(a)_{R x}$ the hepatocyte specific IONIS-APO(a)$\mathrm{L}_{\mathrm{Rx}}$ was developed. The triantennary $\mathrm{N}$-acetylgalactosamine complex ( $\left.\mathrm{GalNAc}_{3}\right)$ facilitates the fast and specific uptake by hepatocytes [50]. This modification enhanced the potency of the Apo(a)-ASO by $>30$ times [51]. Since Apo(a) is targeted VLDL is produced and there is no fat accumulation in the liver.

The IONIS-APO $(\mathrm{a})_{\mathrm{Rx}}$ phase 2 trial confirmed the positive results regarding effectivity and safety [51]. In 64 participants IONIS-APO $(\mathrm{a})_{\mathrm{Rx}}$ was applied subcutaneously in an escalating-dose manner for 12 weeks $(100 \mathrm{mg}, 200 \mathrm{mg}$, and $300 \mathrm{mg}$, each once a week for 4 weeks) versus placebo. Two cohorts were formed according to $\mathrm{Lp}(\mathrm{a})$ baseline levels: cohort A: $\mathrm{Lp}$ (a) $125-437 \mathrm{nmol} / \mathrm{l}$ (placebo group: mean $251.6 \mathrm{nmol} / 1$ and median $216.3 \mathrm{nmol} / \mathrm{l}$, verum group: mean $254 \mathrm{nmol} / 1$, median $261.4 \mathrm{nmol} / \mathrm{l}$ ) and cohort B: Lp(a) $\geq 438 \mathrm{nmol} / 1$ (placebo group: mean $488.3 \mathrm{nmol} / 1$ and median $498.3 \mathrm{nmol} / \mathrm{l}$, verum group: mean $444.9 \mathrm{nmol} / 1$, median $457.6 \mathrm{nmol} / \mathrm{l})$. The primary efficacy endpoint was reduction of $L p(a)$ at day 85 or 99 . Secondary endpoints were effects on other lipoproteins and risk factors.

In both cohorts $\mathrm{Lp}$ (a) was reduced significantly: cohort $\mathrm{A}-66.8 \%$, cohort $\mathrm{B}-71.6 \%$ at day 85/99. Additionally, levels of LDL-c, ApoB, and oxidised phospholipids (OxPL) were reduced significantly in both cohorts. LDLc was lowered by $13.0 \%$ in cohort A and by $23.9 \%$ in cohort B, ApoB by 11.3 and $18.5 \%$, respectively, OxPL-ApoB by 35.2 and $42.5 \%$, respectively, and OxLP-Apo(a) 26.6 and $36.7 \%$, respectively. Baseline statin therapy had no significant effect on these results. The treatment was safe and well tolerated. Two myocardial infarctions and one episode of angina pectoris in high-risk patients were not assessed as treatment related. Injection site reactions occurred in $10 \%$ in cohort A and in 19\% in cohort B (one participant stopped treatment).

Another phase 1/2a first-in-man trial [51] was done with the GalNAc 3 modified IONIS-APO(a)- $\mathrm{L}_{\mathrm{Rx}^{\prime}}$ in healthy volunteers with levels of $\mathrm{Lp}(\mathrm{a}) \geq 75 \mathrm{nmol} / \mathrm{l}$. In the single-dose phase participants $(n=28)$ received one subcutaneous injec- tion of $10,40,80$, or $120 \mathrm{mg}$ versus placebo. In the multiple-dose phase $(n=30)$ IONIS-APO $(\mathrm{a}) \mathrm{L}_{\mathrm{Rx}} 10 \mathrm{mg}, 20 \mathrm{mg}$, or $40 \mathrm{mg}$ were administered at days $1,3,5,8,15$, and 22 versus placebo. The primary efficacy endpoint was reduction of $\mathrm{Lp}$ (a) at day 30 (single-dose phase) and day 36 (multiple-dose phase). Baseline levels of $\mathrm{Lp}$ (a) were $147.8 \mathrm{nmol} / \mathrm{l}$ (mean) and $128.6 \mathrm{nmol} / 1$ (median) in the single-dose phase and $153.8 \mathrm{nmol} / \mathrm{l}$ (mean) and $145.6 \mathrm{nmol} / \mathrm{l}$ (median) in the multiple-dose phase.

In the single ascending dose phase $\mathrm{Lp}(\mathrm{a})$ was reduced significantly in a dose-dependent manner at day 30 . The mean treatment differences versus placebo $(+2.8 \%)$ were $24.8 \%$ (10 mg group), $35.1 \%$ (20 mg group), $48.2 \%$ (40 mg group), $82.5 \%$ ( $80 \mathrm{mg}$ group), and $84.5 \%$ (120 $\mathrm{mg}$ group). The reduction was still significant after 90 days (46\% in the $80 \mathrm{mg}$ group and $44 \%$ in the $120 \mathrm{mg}$ group). Also in the multiple ascending dose phase $\mathrm{Lp}(\mathrm{a})$ was reduced significantly. The treatment differences versus placebo were $59.4 \%$ (10 mg group), 72.3 (20 mg group), and $82.4 \%$ (40 mg group). At day 113 after the last application the lowering effect was still significant with $39 \%$ (10 mg group), $53 \%$ (20 mg group), and 58\% (40 mg group).

The results of the biggest conducted IONIS-APO(a)- $\mathrm{L}_{\mathrm{Rx}}$ (AKCEA-APO $(a)-L_{R x}$ ) phase 2 trial were presented at the AHA Scientific Sessions, Late-Breaking Clinical Trial Presentation, on 10 November 2018 [52]. The trial was a randomized, double-blind, placebo-controlled, and dose-ranging trial in 286 patients with established CVD and high levels of $\mathrm{Lp}$ (a) (baseline mean of approximately $100 \mathrm{mg} / \mathrm{dl}$ [250 nmol/l]). Five cohorts were compared: $20 \mathrm{mg}$ were administered every 4 weeks, $40 \mathrm{mg}$ every 4 weeks, $20 \mathrm{mg}$ every 2 weeks, $60 \mathrm{mg}$ every 4 weeks, and $20 \mathrm{mg}$ every week, each for 6-12 months. The primary efficacy endpoint was percent change in $\mathrm{Lp}(\mathrm{a})$ from baseline at 6 months.

AKCEA-APO(a)-LRx decreased Lp(a) in all groups (20 mg every 4 weeks: $-35 \%$, $40 \mathrm{mg}$ every 4 weeks $-56 \%$, $20 \mathrm{mg}$ every 2 weeks: $-58 \%$ ). The effect was even greater in the highest doses $(60 \mathrm{mg}$ every 4 weeks: $-72 \%, 20 \mathrm{mg}$ weekly: $-80 \%$ ) and in about $81 \%$ and $98 \%$, respectively, $\mathrm{Lp}$ (a) levels $<50 \mathrm{mg} / \mathrm{dl}$ were achieved. The completion rate was high (90\%) and comparable in both groups (verum $12.1 \%$, placebo $14.9 \%$ ). There were no severe safety concerns and few adverse events. Injection site reactions were the most common (26\%) with one patient discontinuing.

\section{Conclusion}

The new developments of lipid-modifying drugs will allow a more effective reduction of LDL-c and $\mathrm{Lp}(\mathrm{a})$ and a more patient-individualised therapy. LDL-c treatment goals and even lower levels than recommended by guidelines today can be reached. The first outcome trials show that car- 
diovascular events are reduced as a consequence. If the Lp(a) lowering capacity of PCSK9 inhibitors contributes to this favourable outcome is unclear. IONIS-APO $(a)_{\mathrm{Rx}}$ is the first antisense oligonucleotide to reduce specifically $\mathrm{Lp}(\mathrm{a})$. Phase 1 and 2 trials showed the significant reduction of $\mathrm{Lp}(\mathrm{a})$ and a very promising safety profile. The $\mathrm{GalNAc}_{3}$ modified molecule IONIS-APO(a)- $\mathrm{L}_{\mathrm{Rx}}$ was developed for fast and specific uptake by hepatocytes which increased the potency more than 30 times. The highest dose of AKCEA$\mathrm{APO}(\mathrm{a})-\mathrm{L}_{\mathrm{Rx}}$ reduced $\mathrm{Lp}(\mathrm{a})$ in the phase $2 \mathrm{a}$ trial by $80 \%$ and in $98 \%$ of the participants $\mathrm{Lp}$ (a) was lowered to $<50 \mathrm{mg} / \mathrm{dl}$, the recommended threshold.

The high effectivity and the favourable tolerability and safety data of these trials raise the expectation that an outcome trial might reproduce these findings and that this significant reduction of $\mathrm{Lp}(\mathrm{a})$ might reduce cardiovascular events. The data regarding reduction of cardiovascular events by lowering Lp(a) via lipoprotein apheresis support this expectation. AKCEA-APO(a)- $\mathrm{L}_{\mathrm{Rx}}$ reduces other lipoproteins and oxidised phospholipids which might contribute to the expected beneficial clinical effects.

The Apo(a)-ASO is the first drug to lower Lp(a) specifically, to a great extent, and with a promising safety profile. This, for the first time, will allow cardiovascular end point trials elucidating if lowering $\mathrm{Lp}$ (a) specifically reduces cardiovascular events.

\section{Compliance with ethical guidelines}

Conflict of interest A. Vogt has received speakers' honoraria for presentations and advisory board activities by Aegerion, Amgen, Berlin Chemie, Fresenius, Genzyme, a Sanofi company, Kaneka, OmniaMed, Regeneron, Sanofi. AV has received research support by Merck Sharp \& Dohme.

Ethical standards This article does not contain any studies with human participants or animals performed by any of the authors.

Open Access This article is distributed under the terms of the Creative Commons Attribution 4.0 International License (http:// creativecommons.org/licenses/by/4.0/), which permits unrestricted use, distribution, and reproduction in any medium, provided you give appropriate credit to the original author(s) and the source, provide a link to the Creative Commons license, and indicate if changes were made.

\section{References}

1. Berg K (1963) A new serum type system in man-the Lp system. Acta Pathol Microbiol Scand 59:369-382

2. Erqou S, Thompson A, Di Angelantonio E, Saleheen D, Kaptoge S, Marcovina S, Danesh J (2010) Apolipoprotein(a) isoforms and the risk of vascular disease: systematic review of 40 studies involving 58,000 participants. J Am Coll Cardiol 55(19):2160-2167. https:// doi.org/10.1016/j.jacc.2009.10.080

3. Kamstrup PR, Benn M, Tybjaerg-Hansen A, Nordestgaard BG (2008) Extreme lipoprotein(a) levels and risk of myocardial infarction in the general population: the Copenhagen City Heart
Study. Circulation 117(2):176-184. https://doi.org/10.1161/ CIRCULATIONAHA.107.715698

4. Laschkolnig A, Kollerits B, Lamina C, Meisinger C, Rantner B, Stadler M, Peters A, Koenig W, Stockl A, Dahnhardt D, Boger CA, Kramer BK, Fraedrich G, Strauch K, Kronenberg F (2014) Lipoprotein (a) concentrations, apolipoprotein (a) phenotypes, and peripheral arterial disease in three independent cohorts. Cardiovasc Res 103(1):28-36. https://doi.org/10.1093/cvr/cvu107

5. Kamstrup PR, Tybjaerg-Hansen A, Nordestgaard BG (2014) Elevated lipoprotein(a) and risk of aortic valve stenosis in the general population. J Am Coll Cardiol 63(5):470-477. https://doi.org/10. 1016/j.jacc.2013.09.038

6. Kronenberg F, Utermann G (2013) Lipoprotein(a): resurrected by genetics. J Intern Med 273(1):6-30. https://doi.org/10.1111/j.13652796.2012.02592.x

7. Clarke R, Peden JF, Hopewell JC, Kyriakou T, Goel A, Heath SC, Parish S, Barlera S, Franzosi MG, Rust S, Bennett D, Silveira A, Malarstig A, Green FR, Lathrop M, Gigante B, Leander K, de Faire U, Seedorf U, Hamsten A, Collins R, Watkins H, Farrall M, Consortium P (2009) Genetic variants associated with Lp(a) lipoprotein level and coronary disease. N Engl J Med 361(26):2518-2528. https://doi.org/10.1056/NEJMoa0902604

8. Kamstrup PR, Tybjaerg-Hansen A, Steffensen R, Nordestgaard BG (2009) Genetically elevated lipoprotein(a) and increased risk of myocardial infarction. JAMA 301(22):2331-2339. https://doi.org/10. 1001/jama.2009.801

9. Kraft HG, Lingenhel A, Kochl S, Hoppichler F, Kronenberg F, Abe A, Muhlberger V, Schonitzer D, Utermann G (1996) Apolipoprotein(a) kringle IV repeat number predicts risk for coronary heart disease. Arterioscler Thromb Vasc Biol 16(6):713-719

10. Kronenberg F, Kronenberg MF, Kiechl S, Trenkwalder E, Santer P, Oberhollenzer F, Egger G, Utermann G, Willeit J (1999) Role of lipoprotein(a) and apolipoprotein(a) phenotype in atherogenesis: prospective results from the Bruneck study. Circulation 100(11):1154-1160

11. Kronenberg F, Neyer U, Lhotta K, Trenkwalder E, Auinger M, Pribasnig A, Meisl T, Konig P, Dieplinger H (1999) The low molecular weight apo(a) phenotype is an independent predictor for coronary artery disease in hemodialysis patients: a prospective followup. J Am Soc Nephrol 10(5):1027-1036

12. Sandholzer C, Saha N, Kark JD, Rees A, Jaross W, Dieplinger H, Hoppichler F, Boerwinkle E, Utermann G (1992) Apo(a) isoforms predict risk for coronary heart disease. A study in six populations. Arterioscler Thromb 12(10):1214-1226

13. Authors/Task Force M, Piepoli MF, Hoes AW, Agewall S, Albus C, Brotons C, Catapano AL, Cooney MT, Corra U, Cosyns B, Deaton C, Graham I, Hall MS, Hobbs FD, Lochen ML, Lollgen H, Marques-Vidal P, Perk J, Prescott E, Redon J, Richter DJ, Sattar N, Smulders Y, Tiberi M, van der Worp HB, van Dis I, Verschuren WM, Additional Contributor: Simone B, Document R, De Backer G, Roffi M, Aboyans V, Bachl N, Bueno H, Carerj S, Cho L, Cox J, De Sutter J, Egidi G, Fisher M, Fitzsimons D, Franco OH, Guenoun M, Jennings C, Jug B, Kirchhof P, Kotseva K, Lip GY, Mach F, Mancia G, Bermudo FM, Mezzani A, Niessner A, Ponikowski P, Rauch B, Ryden L, Stauder A, Turc G, Wiklund O, Windecker S, Zamorano JL (2016) 2016 European Guidelines on cardiovascular disease prevention in clinical practice: The Sixth Joint Task Force of the European Society of Cardiology and Other Societies on Cardiovascular Disease Prevention in Clinical Practice (constituted by representatives of 10 societies and by invited experts): Developed with the special contribution of the European Association for Cardiovascular Prevention \& Rehabilitation (EACPR). Eur J Prev Cardiol 23 (11):NP1-NP96. https://doi.org/10.1177/2047487316653709

14. Grundy SM, Stone NJ, Bailey AL, Beam C, Birtcher KK, Blumenthal RS, Braun LT, Braun LT, de Ferranti S, Faiella-Tommasino J, Forman DE, Goldberg R, Heidenreich PA, Hlatky MA, 
Jones DW, Lloyd-Jones D, Lopez-Pajares N, Ndumele CE, Orringer CE, Peralta CA, Saseen JJ, Smith SC Jr., Sperling L, Virani SS, Yeboah J (2018) 2018 AHA/ACC/AACVPR/AAPA/ABC/ ACPM/ADA/AGS/APhA/ASPC/NLA/PCNA Guideline on the Management of Blood Cholesterol: Executive Summary: A Report of the American College of Cardiology/American Heart Association Task Force on Clinical Practice Guidelines. J Am Coll Cardiol. https://doi.org/10.1016/j.jacc.2018.11.002

15. Nordestgaard BG, Chapman MJ, Ray K, Boren J, Andreotti F, Watts GF, Ginsberg H, Amarenco P, Catapano A, Descamps OS, Fisher E, Kovanen PT, Kuivenhoven JA, Lesnik P, Masana L, Reiner Z, Taskinen MR, Tokgozoglu L, Tybjaerg-Hansen A (2010) Lipoprotein(a) as a cardiovascular risk factor: current status. Eur Heart J 31(23):2844-2853. https://doi.org/10.1093/eurheartj/ehq386

16. Khera AV, Everett BM, Caulfield MP, Hantash FM, Wohlgemuth J, Ridker PM, Mora S (2014) Lipoprotein(a) concentrations, rosuvastatin therapy, and residual vascular risk: an analysis from the JUPITER Trial (Justification for the Use of Statins in Prevention: an Intervention Trial Evaluating Rosuvastatin). Circulation 129(6):635-642. https://doi.org/10.1161/CIRCULATIONAHA. 113.004406

17. Kei A, Liberopoulos E, Tellis K, Rizzo M, Elisaf M, Tselepis A (2013) Effect of hypolipidemic treatment on emerging risk factors in mixed dyslipidemia: a randomized pilot trial. Eur J Clin Invest 43(7):698-707. https://doi.org/10.1111/eci.12095

18. Tziomalos K, Athyros VG, Wierzbicki AS, Mikhailidis DP (2009) Lipoprotein a: where are we now? Curr Opin Cardiol 24(4):351357. https://doi.org/10.1097/HCO.0b013e32832ac21a

19. Moutzouri E, Liberopoulos EN, Tellis CC, Milionis HJ, Tselepis AD, Elisaf MS (2013) Comparison of the effect of simvastatin versus simvastatin/ezetimibe versus rosuvastatin on markers of inflammation and oxidative stress in subjects with hypercholesterolemia. Atherosclerosis 231(1):8-14. https://doi.org/10.1016/j. atherosclerosis.2013.08.013

20. Carlson LA, Hamsten A, Asplund A (1989) Pronounced lowering of serum levels of lipoprotein $\mathrm{Lp}(\mathrm{a})$ in hyperlipidaemic subjects treated with nicotinic acid. J Intern Med 226(4):271-276

21. Goldberg A, Alagona P Jr., Capuzzi DM, Guyton J, Morgan JM, Rodgers J, Sachson R, Samuel P (2000) Multiple-dose efficacy and safety of an extended-release form of niacin in the management of hyperlipidemia. Am J Cardiol 85(9):1100-1105

22. Bruckert E, Labreuche J, Amarenco P (2010) Meta-analysis of the effect of nicotinic acid alone or in combination on cardiovascular events and atherosclerosis. Atherosclerosis 210(2):353-361. https://doi.org/10.1016/j.atherosclerosis.2009.12.023

23. Group HTC, Landray MJ, Haynes R, Hopewell JC, Parish S, Aung T, Tomson J, Wallendszus K, Craig M, Jiang L, Collins R, Armitage J (2014) Effects of extended-release niacin with laropiprant in high-risk patients. N Engl J Med 371(3):203-212. https://doi.org/ 10.1056/NEJMoa1300955

24. Bundesausschuss G (2010) Richtlinie des Gemeinsamen Bundesausschusses zu Untersuchungs- und Behandlungsmethoden der vertragsärztlichen Versorgung. Bundesanzeiger 109:2561

25. Derfler K, Steiner S, Sinzinger H (2015) Lipoprotein-apheresis: Austrian consensus on indication and performance of treatment. Wien Klin Wochenschr 127(15-16):655-663. https://doi.org/10. 1007/s00508-015-0833-4

26. Stefanutti C (2010) The 2009 2nd Italian Consensus Conference on LDL-apheresis. Nutr Metab Cardiovasc Dis 20(10):761-762. https://doi.org/10.1016/j.numecd.2010.04.007

27. Thompson GR (2008) Recommendations for the use of LDL apheresis. Atherosclerosis 198(2):247-255. https://doi.org/10. 1016/j.atherosclerosis.2008.02.009

28. Jaeger BR, Richter Y, Nagel D, Heigl F, Vogt A, Roeseler E, Parhofer K, Ramlow W, Koch M, Utermann G, Labarrere CA, Seidel D, Group of (2009) Longitudinal cohort study on the effective- ness of lipid apheresis treatment to reduce high lipoprotein(a) levels and prevent major adverse coronary events. Nat Clin Pract Cardiovasc Med 6(3):229-239. https://doi.org/10.1038/ncpcardio1456

29. Rosada A, Kassner U, Vogt A, Willhauck M, Parhofer K, Steinhagen-Thiessen E (2014) Does regular lipid apheresis in patients with isolated elevated lipoprotein(a) levels reduce the incidence of cardiovascular events? Artif Organs 38(2):135-141. https://doi.org/ 10.1111/aor.12135

30. Schettler VJ, Neumann CL, Peter C, Zimmermann T, Julius U, Roeseler E, Heigl F, Ramlow W, Blume H, Scientific Board of GftGAWG (2015) First data from the German Lipoprotein Apheresis Registry (GLAR). Atheroscler Suppl 18:41-44. https://doi.org/10. 1016/j.atherosclerosissup.2015.02.006

31. Schettler VJJ, Neumann CL, Peter C, Zimmermann T, Julius U, Roeseler E, Heigl F, Grutzmacher P, Blume H, Scientific Board of GftGAWG (2017) Current insights into the German Lipoprotein Apheresis Registry (GLAR)—Almost 5 years on. Atheroscler Suppl 30:50-55. https://doi.org/10.1016/j.atherosclerosissup.2017. 05.006

32. Leebmann J, Roeseler E, Julius U, Heigl F, Spitthoever R, Heutling D, Breitenberger P, Maerz W, Lehmacher W, Heibges A, Klingel R, ProLiFe Study G (2013) Lipoprotein apheresis in patients with maximally tolerated lipid-lowering therapy, lipoprotein(a)-hyperlipoproteinemia, and progressive cardiovascular disease: prospective observational multicenter study. Circulation 128(24):2567-2576. https://doi.org/10.1161/CIRCULATIONAHA. 113.002432

33. Roeseler E, Julius U, Heigl F, Spitthoever R, Heutling D, Breitenberger P, Leebmann J, Lehmacher W, Kamstrup PR, Nordestgaard BG, Maerz W, Noureen A, Schmidt K, Kronenberg F, Heibges A, Klingel R, ProLiFe-Study G (2016) Lipoprotein apheresis for lipoprotein(a)-associated cardiovascular disease: prospective 5 years of follow-up and apolipoprotein(a) characterization. Arterioscler Thromb Vasc Biol 36(9):2019-2027. https://doi.org/10. 1161/ATVBAHA.116.307983

34. Safarova MS, Ezhov MV, Afanasieva OI, Matchin YG, Atanesyan RV, Adamova IY, Utkina EA, Konovalov GA, Pokrovsky SN (2013) Effect of specific lipoprotein(a) apheresis on coronary atherosclerosis regression assessed by quantitative coronary angiography. Atheroscler Suppl 14(1):93-99. https://doi.org/10.1016/ j.atherosclerosissup.2012.10.015

35. von Dryander M, Fischer S, Passauer J, Muller G, Bornstein SR, Julius U (2013) Differences in the atherogenic risk of patients treated by lipoprotein apheresis according to their lipid pattern. Atheroscler Suppl 14(1):39-44. https://doi.org/10.1016/j. atherosclerosissup.2012.10.005

36. Winters JL (2011) Lipid apheresis, indications, and principles. J Clin Apher 26(5):269-275. https://doi.org/10.1002/jca .20299

37. Sabatine MS, Giugliano RP, Wiviott SD, Raal FJ, Blom DJ, Robinson J, Ballantyne CM, Somaratne R, Legg J, Wasserman SM, Scott R, Koren MJ, Stein EA, Open-Label Study of Long-Term Evaluation against LDLCI (2015) Efficacy and safety of evolocumab in reducing lipids and cardiovascular events. N Engl J Med. https:// doi.org/10.1056/NEJMoa1500858

38. Robinson JG, Farnier M, Krempf M, Bergeron J, Luc G, Averna M, Stroes ES, Langslet G, Raal FJ, Shahawy ME, Koren MJ, Lepor NE, Lorenzato C, Pordy R, Chaudhari U, Kastelein JJ, Investigators OLT (2015) Efficacy and safety of alirocumab in reducing lipids and cardiovascular events. N Engl J Med. https://doi.org/10.1056/ NEJMoa1501031

39. Gaudet D, Kereiakes DJ, McKenney JM, Roth EM, Hanotin C, Gipe D, Du Y, Ferrand AC, Ginsberg HN, Stein EA (2014) Effect of alirocumab, a monoclonal proprotein convertase subtilisin/kexin 9 antibody, on lipoprotein(a) concentrations (a pooled analysis of $150 \mathrm{mg}$ every two weeks dosing from phase 2 trials). Am J Cardiol 114(5):711-715. https://doi.org/10.1016/j.amjcard.2014.05.060 
40. Raal FJ, Honarpour N, Blom DJ, Hovingh GK, Xu F, Scott R, Wasserman SM, Stein EA, Investigators T (2015) Inhibition of PCSK9 with evolocumab in homozygous familial hypercholesterolaemia (TESLA Part B): a randomised, double-blind, placebocontrolled trial. Lancet 385(9965):341-350. https://doi.org/10. 1016/S0140-6736(14)61374-X

41. Desai NR, Kohli P, Giugliano RP, O’Donoghue ML, Somaratne R, Zhou J, Hoffman EB, Huang F, Rogers WJ, Wasserman SM, Scott R, Sabatine MS (2013) AMG145, a monoclonal antibody against proprotein convertase subtilisin kexin type 9 , significantly reduces lipoprotein(a) in hypercholesterolemic patients receiving statin therapy: an analysis from the LDL-C Assessment with Proprotein Convertase Subtilisin Kexin Type 9 Monoclonal Antibody Inhibition Combined with Statin Therapy (LAPLACE)-Thrombolysis in Myocardial Infarction (TIMI) 57 trial. Circulation 128(9):962-969. https://doi.org/10.1161/CIRCULATIONAHA.113.001969

42. O’Donoghue ML, Fazio S, Giugliano RP, Stroes ESG, Kanevsky E, Gouni-Berthold I et al (2018) Lipoprotein(a), PCSK9 inhibition and cardiovascular risk: insights from the FOURIER trial. Circulation. https://doi.org/10.1161/CIRCULATIONAHA.118.037184

43. Parhofer KG (2012) Mipomersen: evidence-based review of its potential in the treatment of homozygous and severe heterozygous familial hypercholesterolemia. Core Evid 7:29-38. https://doi.org/10. 2147/CE.S25239

44. Rader DJ, Kastelein JJ (2014) Lomitapide and mipomersen: two first-in-class drugs for reducing low-density lipoprotein cholesterol in patients with homozygous familial hypercholesterolemia. Circulation 129(9):1022-1032. https://doi.org/10.1161/ CIRCULATIONAHA.113.001292

45. Santos RD, Raal FJ, Catapano AL, Witztum JL, SteinhagenThiessen E, Tsimikas S (2015) Mipomersen, an antisense oligonucleotide to apolipoprotein B-100, reduces lipoprotein(a) in various populations with hypercholesterolemia: results of 4 phase III trials. Arterioscler Thromb Vasc Biol 35(3):689-699. https://doi.org/10. 1161/ATVBAHA.114.304549

46. Waldmann E, Vogt A, Crispin A, Altenhofer J, Riks I, Parhofer KG (2017) Effect of mipomersen on LDL-cholesterol in patients with severe LDL-hypercholesterolaemia and atherosclerosis treated by lipoprotein apheresis (The MICA-Study). Atherosclerosis 259:20-25. https://doi.org/10.1016/j.atherosclerosis.2017.02. 019
47. Waldmann E, Vogt A, Crispin A, Altenhofer J, Riks I, Parhofer KG (2018) Corrigendum to: "Effect of mipomersen on LDLcholesterol in patients with severe LDL-hypercholesterolaemia and atherosclerosis treated by lipoprotein apheresis (The MICAStudy). Atherosclerosis 275:461-462. https://doi.org/10.1016/j. atherosclerosis.2018.05.020

48. Merki E, Graham M, Taleb A, Leibundgut G, Yang X, Miller ER, Fu W, Mullick AE, Lee R, Willeit P, Crooke RM, Witztum JL, Tsimikas S (2011) Antisense oligonucleotide lowers plasma levels of apolipoprotein (a) and lipoprotein (a) in transgenic mice. J Am Coll Cardiol 57(15):1611-1621. https://doi.org/10.1016/j. jacc.2010.10.052

49. Tsimikas S, Viney NJ, Hughes SG, Singleton W, Graham MJ, Baker BF, Burkey JL, Yang Q, Marcovina SM, Geary RS, Crooke RM, Witztum JL (2015) Antisense therapy targeting apolipoprotein(a): a randomised, double-blind, placebo-controlled phase 1 study. Lancet 386(10002):1472-1483. https://doi.org/10.1016/S01406736(15)61252-1

50. Prakash TP, Graham MJ, Yu J, Carty R, Low A, Chappell A, Schmidt K, Zhao C, Aghajan M, Murray HF, Riney S, Booten SL, Murray SF, Gaus H, Crosby J, Lima WF, Guo S, Monia BP, Swayze EE, Seth PP (2014) Targeted delivery of antisense oligonucleotides to hepatocytes using triantennary $\mathrm{N}$-acetyl galactosamine improves potency 10-fold in mice. Nucleic Acids Res 42(13):8796-8807. https://doi.org/10.1093/nar/gku531

51. Viney NJ, van Capelleveen JC, Geary RS, Xia S, Tami JA, Yu RZ, Marcovina SM, Hughes SG, Graham MJ, Crooke RM, Crooke ST, Witztum JL, Stroes ES, Tsimikas S (2016) Antisense oligonucleotides targeting apolipoprotein(a) in people with raised lipoprotein(a): two randomised, double-blind, placebo-controlled, doseranging trials. Lancet 388(10057):2239-2253. https://doi.org/10. 1016/S0140-6736(16)31009-1

52. Tsimikas S, Karwatowska-Prokopczuk E, Gouni-Berthold I, Tardif JC, Baum S, Steinhagen-Thiessen E, Shapiro M, Stroes E, Moriarty P, Nordestgaard B, Guerriero J, Viney N, O'Dea L, Witztum J, AKCEA-APO(a)-LRx Study Investigators (2018) Safety and efficacy of AKCEA-APO(a)-LRx to lower lipoprotein(a) levels in patients with established cardiovascular disease: A phase 2 dose-ranging trial. https://www.tctmd.com/slide/safety-and-efficacy-akceaapoa-lrx-lower-lipoproteina-levels-patients-established. Accessed 14 Jan 2019 